\title{
Chapter 5 \\ How Are the Prospects for Refugees to Become Active Members of Society? - The Vision and Practices in Turkish Adult Education
}

\author{
Armağan Erdoğan, K. Onur Unutulmaz, Suna G. Aydemir, \\ and M. Murat Erdoğan
}

\section{Introduction}

Adult education (AE) gives individuals the opportunity to gain new skills and expand their knowledge throughout their life (Kowalski 1988; Tight 1996; Jarvis 2010). It has, therefore, different perspectives, benefits and limitations from the formal education. Adult education has a lifelong perspective for any age group and is designed both for the personal development of individuals and also for the public good (Jarvis 2010, Toprak and Erdoğan 2012). In this sense, it has a significant role for the development of human resources for any country. Disadvantaged groups who have less opportunities in formal education for any reasons appear as specific targets for AE (Anderson and Niomi 1969). In the contemporary era the number of people, who suffered from migration and particularly forced migration, increased dramatically throughout the world. These unstable circumstances put an important role on adult education mechanisms both for the "new comers", who have multidimensional vulnerabilities, and also for the countries who are hosting those people. Adult education in this sense is one of the inevitable tools of the social cohesion as stated by Kersh and others in the introduction to this edition. Nevertheless, although the necessity of adult education is evident, it is not always easy to implement functional AE systems and programs. Capacity and resources are the key elements to

\footnotetext{
A. Erdoğan

Center for Higher Education Studies, Social Sciences University of Ankara, Ankara, Turkey

K. O. Unutulmaz $(\bowtie)$

Department of International Relations, Social Sciences University of Ankara, Ankara, Turkey

S. G. Aydemir

Department of Political Science, Turkish-German University, Istanbul, Turkey

M. M. Erdoğan

Migration and Integration Research Center-TAGU at Turkish-German University,

Istanbul, Turkey
} 
realize the AE programs, particularly for the forced migration cases where both emergency and the numbers create a great challenge and barrier for their access (Pennacchia et al. 2018). EduMAP started from this perspective and aimed to search for good examples of adult education programs leading the vulnerable groups towards active participatory citizenship in 28 EU countries and Turkey. This chapter, derived from our research, discusses Turkey's unique experience of the Syrian refugees in the last 10 years by focusing on possibilities and limitations of the $\mathrm{AE}$ programs designed for these groups.

The world has been witnessing one of the biggest humanitarian crises since 2011. Due to the Civil War in Syria, almost half of its population were forced to be displaced. Out of 22 million population of Syria, 6.6 million people had to leave the country, 7-8 million internally displaced, almost 500 thousand people died and hundreds of thousands were injured (UNHCR, 2019). The majority of the displaced Syrians found shelter in the neighboring countries such as Turkey, Lebanon, and Jordan. Turkey was confronted with a dramatic refugee flow due to Syrian Civil War starting in March 2011 (Erdoğan 2014, 2018; Eroglu et al. 2017). As of March, 2020 , there are over 4.1 million registered refugees, of which 3.6 million are from Syria (DGMM 2020). In other words, 54\% of Syrian refugees, half the population who had to leave Syria is being hosted by Turkey. Turkey had only 58 thousand refugees in 2011, and received 4.1 million refugees within a few years and became the country hosting the largest refugee population in the world since 2014 (IOM 2017,34). Refugees currently make 5\% of the total 83 million population in Turkey and even in some border cities like Kilis, Syrian population is $80,61 \%$ - much higher than the local population (DGMM 2020). Another significant point regarding the refugee settlement is that approximately more than $97 \%$ of refugees live in the towns or cities as "urban refugees" and only small numbers live in the camps.

Receiving a tremendous amount of population in a short time creates inevitable challenges for Turkey which had been a transit country rather than a target country before. Furthermore, there is still no clear prospects about when the war might end and peace will be achieved in Syria even after 9 years. The unclear situation in their homeland weakens the option for Syrian refugees to return. Studies about the attitudes of Syrian refugees in Turkey show that the majority wish to stay permanently in Turkey even if the war ends (Erdoğan 2017). Relatively high but at the same time "very fragile" acceptance rate of Turkish society in spite of high refugee numbers eased this very challenging and sensitive situation so far (Erdoğan 2020). However potential problem areas and anxiety exist and clear social policies are needed for a better integration (Erdoğan 2014, 2020; Unutulmaz 2017).

It can be said that Turkey's policy for the Syrian refugees is based on four axes: open door policy, temporary protections status, emergency management and perception of temporariness. Turkey adopted open door policy on its East and SouthEast borders during these years to shelter the Syrians escaping from the effects of the war; and it resulted in a few years in a massive influx of asylum seekers not only from Syria but from other countries such as Iran, Afghanistan, and Iraq, heading to Turkey either for settlement or for transit migration (see the Fig. 5.1). The legal status of the Syrian refugees who come to Turkey as a result of civil war after 2011 


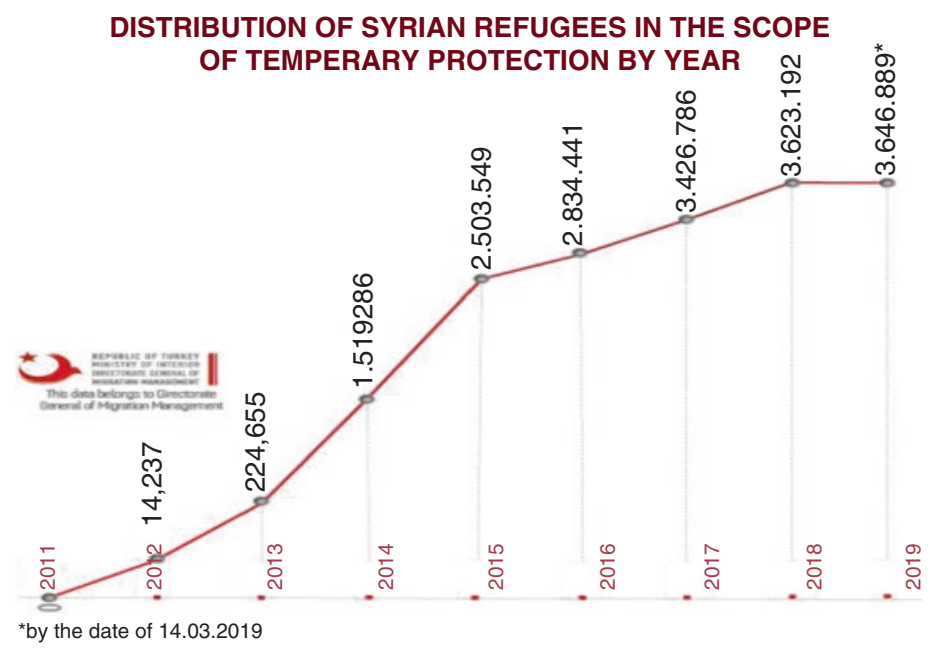

Source: Directory General of Migration Management (DGMM), Ministry of Interior.

Fig. 5.1 Increase of Syrian refugees in years in Turkey. (Source: Directory General of Migration Management (DGMM), Ministry of Interior)

is "temporary" protection, because of the geographical limitation Turkey put in the Geneva Convention in 1951. Emergency based policies were needed for the massive number of refugees in the first years; but to define them as "guests" rather than "refugees" put them in a "temporary" status both in terms of legislation and policies. It can be said that temporariness perception hinders the future perspectives and integration processes of Syrian refugees (Erdoğan 2017).

Undoubtedly, one of the most important elements of living together in harmony is education and inclusion of the newcomers who in many ways are vulnerable. This chapter presents a critical analysis of the Turkish experience of adult education (AE) in the context of the current refugee situation with a focus on its role in helping this vulnerable community to become active members of society. After analysing the background information about the mass influx of refugees in Turkey since 2011, the historical development and current structure and practices of $\mathrm{AE}$ and Lifelong Learning (LLL) will be examined. Findings of our research show that all its stakeholders perceive the AE sector as crucial for the empowerment of Syrian refugees. $\mathrm{AE}$ appears to be the necessary framework for the transformation of refugees into active members of Turkish society through their social, economic and cultural inclusion. 


\section{Methodology}

The information and discussions presented in this Chapter are based on data collected through a mix of techniques in line with the overall EduMAP research design. The backgrounds, current frameworks, and relevant statistics regarding both the Syrian refugees and AE sector in Turkey present extensive data collected through comprehensive desk research. The main focus has been on the refugees as vulnerable young adults in Turkey, as sampling the country outside EU28. Following this target of the project and in line with the coordinator team meetings and the documents, guides and interview materials were prepared to collect data from "good practices", having the same methodological approach decided by the Coordination Team and the Team Leaders of EduMAP.

The discussion over how the Turkish AE sector responded to the inflow of Syrian refugees, however, utilized primary data collected through a multi-sited fieldwork on three identified Good Practice (GP) cases. In this context, interviews and focus group meetings were conducted with more than 50 individuals including decision makers at national level and administrators, project coordinators, educators, and former and current learners at selected AE programs targeting vulnerable young adults in Istanbul, Ankara, Gaziantep, and Soma. The collected primary data was analysed using a qualitative data analysis software, namely MAXQDA, using the codes collectively formed by all EduMAP partners, adapted to the Turkish context when necessary. Limitations of the research are mainly based on working with the vulnerable groups such as communicating through and relying on translators; the fact that their legal status of being under temporary protection intensified the idea of temporariness, and their lack of knowledge about the conceptual definitions of the research such as AE and APC.

\section{Background and Relevant Statistics of the Syrian Population in Turkey}

It would be useful to overview some statistics relevant to the scope of our research to set the background for the Syrian population in Turkey. A large majority of the Syrian population in Turkey are under the age of 30, while the number of young adults in the scope of EduMAP age group of 15 to 30 is 1.181.261 (see Table 5.1). Therefore, there is a dynamic and young population in question, which makes providing education one of the major challenges for Turkey. Another striking point of the demographic structure of the Syrian refugees in Turkey is the gender imbalance. Male population accounting for the $54.2 \%$ of the population is much higher than female population, and this imbalance is even higher in the youth population. This affects the education policies and services as well as the employment opportunities. Additionally, cultural codes and family structure do not leave much room for women to go out; the male population in the public is higher and therefore particularly 
Table 5.1 Distribution by gender and age of Syrian Refugees

\begin{tabular}{|c|c|c|c|}
\hline \multicolumn{4}{|c|}{$\begin{array}{l}\text { DISTRIBUTION BY AGE AND GENDER OF REGISTERED SYRIAN } \\
\text { REFUGEES RECORDED BY TAKING BIOMETRIC DATA }\end{array}$} \\
\hline AGE & MALE & FEMALE & TOTAL \\
\hline TOTAL & 1.978 .313 & 1.668 .576 & 3.646 .889 \\
\hline 0-4 & 258.180 & 241.149 & 499.329 \\
\hline $5-9$ & 260.017 & 244.426 & 504.443 \\
\hline $10-14$ & 202.466 & 187.526 & 389.992 \\
\hline $15-18$ & 149.512 & 123.652 & 273.164 \\
\hline $19-24$ & 312.230 & 229.989 & 551.219 \\
\hline $25-29$ & 208.987 & 147.891 & 356.878 \\
\hline $30-34$ & 172.934 & 126.217 & 299.151 \\
\hline $35-39$ & 122.508 & 96.070 & 218.578 \\
\hline $40-44$ & 80.964 & 71.131 & 152.095 \\
\hline $45-49$ & 59.981 & 57.043 & 117.024 \\
\hline $50-54$ & 48.680 & 46.318 & 94.998 \\
\hline $55-59$ & 33.941 & 34.078 & 68.019 \\
\hline $60-64$ & 23.841 & 24.396 & 48.237 \\
\hline $65-69$ & 15.822 & 16.294 & 35.116 \\
\hline $70-74$ & 8.985 & 9.570 & 18.555 \\
\hline $75-79$ & 5.058 & 6.238 & 11.296 \\
\hline $80-84$ & 2.800 & 3.501 & 6.301 \\
\hline $85-89$ & 1.565 & 2.024 & 3.589 \\
\hline $90+$ & 842 & 1.063 & 1.905 \\
\hline
\end{tabular}

Source: DGMM, Ministry of Interior

vocational $\mathrm{AE}$ programs need to be planned for men. However, as our findings show, this is also complicated as men prioritize working over attending AE programs.

When we look at the indicators on education, they illustrate the depth of the vulnerability of the young adult refugees. Their educational attainment is based on their self-declaration during their registration. According to a self-declared data, 33\% of the Syrian population is illiterate with $13 \%$ stating that they are literate but with no school experience, displaying the very low education level of the population (Ministry of Development 2016). The school age children (5-17) are over one million and 65\% of them were enrolled into schools in 2019. This can be regarded as a great success on the one hand, but the remaining 400 thousand are great nominees to become members of the much feared "lost generation". Another crucial fact is the high level of drop outs and the decrease of schooling rates in the later ages. While the enrolment rate in primary school is $95 \%$, in secondary school it drops to $45 \%$ and in high schools it is $25 \%$. Schooling rates for girls and boys harbour significant gaps in favour of boys - the only exceptions being the primary school. ${ }^{1}$ In 2018-2019 there were 50 thousand students attending the last year of their high school education.

${ }^{1}$ (377.765 Female Students - 351.231 Male Students)- Kindergarten (34.584 F - 93.791 M), Secondary School (140.638 F - 272.819 E) and in High School (57.528 F - 258.359 M) 
Almost 1.2 million which is $32 \%$ of the Syrian population in Turkey is between 15-29 years old (Ministry of National Education 2019). Therefore, this group is the target group for the AE programs since they missed the formal education opportunity both in their country and in Turkey. Their socio-economic status is also low which directly increases their vulnerability. In the mid and long term this profile is very crucial for the new AE policies. It is necessary to make a well-planned LLL strategy and a high level of AE supply in the coming years. At this point, there is another difficulty that will be faced by policymakers: To increase the quality of the program, a strong finance, which on the one hand requires the re-consent of the society in Turkey about distributing sources as well as an effective management of the international financial resources/opportunities. However, conjectural developments in both contexts are unfavourable. All these testify for the fact that Syrian refugees in Turkey are vulnerable in many more ways than one and providing them with high-quality adult education programs is an extremely difficult yet vital challenge.

In terms of adult education, the law on foreigners has measures under the articles regulating harmonization of immigrants. Article 96 states that "The Directorate General may, to the extent that Turkey's economic and financial capacity deems possible, plan for harmonization activities in order to facilitate mutual harmonization between foreigners, applicants and international protection beneficiaries and the society as well as to equip them with the knowledge and skills to be independently active in all areas of social life". Article 96 goes on to state that "Foreigners may attend courses where the basics of political structure, language, legal system, culture and history of Turkey as well as their rights and obligations are explained. The Directorate General shall promote the courses related to access to public and private goods and services, access to education and economic activities, social and cultural communications, and access to primary healthcare services and, awareness and information activities through distant learning and similar means in cooperation with public institutions and agencies and non-governmental organisations". 2

Temporary Protection Regulation has a whole part on "services to be provided to persons benefiting from temporary protection", health services, education services, access to labour market services, social assistance and services, interpretation services (Erdoğan 2014, 2018). Article 28 refers to education services. "Education activities for foreigners under this Regulation shall be conducted inside and outside temporary accommodation centres under the control and responsibility of the Ministry of National Education [...] In that regard: language education, vocational courses, skills trainings and hobby courses addressing all age groups may be organized depending on the demand. The first piece of legislation regulating matters of immigration and international protection in Turkey, the Law on Foreigners and International Protection, ${ }^{3}$ was passed in 2013. This law included rather vague

\footnotetext{
${ }^{2}$ Law on Foreigners and International Protection (2013): Article 96: https://www.goc.gov.tr/files/ files/law\%20on\%20foreigners\%20and\%20international\%20protection(2).pdf

${ }^{3}$ Full text of the Law is available in 11 languages at http://www.goc.gov.tr/icerik6/11-dilde-yukk_ 327_328_1174_icerik
} 
provisions about education of legal aliens in the country, assigning the authority to make necessary arrangements to the Ministry of National Education (MoNE) (Articles 34 and 59).

Gender equality in education is guaranteed by the constitution and related legislation in Turkey. Basic Law of National Education states that "education institutions are open to everybody regardless of language, race, gender and religion. No privilege shall be granted to any individual, family, group or class" (Article 4). Equal opportunity in education is provided for men and women (Article 8). Nevertheless, the "gender gap" in literacy is quite wide according to many sources including World Economic Forum Reports. Access of Syrian women to adult education is relatively high compared to formal education, however the content and the quality of education are questionable, which does not help much with empowerment of women in active citizenship (Unutulmaz 2019, 13-14).

\section{Historical Development and Current State of the Turkish Adult Education System}

The development of the Turkish AE System is an inseparable part of the Turkish modernization experience. The latter is described in the literature as one of the most radical versions of non-western and late modernization. This section identifies the significant periods that have shaped Turkish $\mathrm{AE}$ in each of the historical periods from the proclamation of the Turkish Republic in the year 1923 until today.

In the twentieth century, the social structure of Turkey has undergone radical change. In 1927 Turkey's population was less than 14 million. In 2018 it exceeded 82 million. Until the 2000s the country's annual population growth rate has usually been over 20\%. While in 1927 the proportion of the urban population was around $24.2 \%$, this ratio increased to $92.3 \%$ as of 2018 (Table 5.2) (Icduygu 2012). In 1955 the rate of adults employed in agriculture was 77.4\% (TurkStat 2012: 27-28). Until 2018 , this ratio decreased to $18.4 \%$. On the other hand, the employment rate in the service sector has exceeded 54\%. These data will help to understand when, why and in which direction adult education policies have changed in terms of purposes, target groups, and priorities. Against this background, it can be argued that the newly urban population, moving from the rural to the industrial regions has been traditionally the major target group of Turkish AE, supporting their socio-cultural, economic and political integration into urban society. 
Table 5.2 Population, annual growth rate of population, province/district centers and town/ villages population

\begin{tabular}{l|l|l|l|l}
\hline $\begin{array}{l}\text { Census } \\
\text { year }\end{array}$ & Population & $\begin{array}{l}\text { Annual growth } \\
(\%)\end{array}$ & $\begin{array}{l}\text { Rate of urban population } \\
(\%)\end{array}$ & $\begin{array}{l}\text { Rate of rural population } \\
(\%)\end{array}$ \\
\hline $\mathbf{1 9 2 7}$ & $13,648,270$ & - & 24.2 & 75.8 \\
\hline $\mathbf{1 9 4 0}$ & $17,820,950$ & 17.03 & 24.4 & 75.6 \\
\hline $\mathbf{1 9 5 0}$ & $20,947,188$ & 21.73 & 25.0 & 75.0 \\
\hline $\mathbf{1 9 6 0}$ & $27,754,820$ & 28.53 & 31.9 & 68.1 \\
\hline $\mathbf{1 9 7 0}$ & $35,605,176$ & 25.19 & 38.5 & 61.5 \\
\hline $\mathbf{1 9 8 0}$ & $44,736,957$ & 20.65 & 43.9 & 56.1 \\
\hline $\mathbf{1 9 9 0}$ & $56,473,035$ & 21.71 & 59.0 & 41.0 \\
\hline $\mathbf{2 0 0 0}$ & $67,803,927$ & 18.28 & 64.9 & 35.1 \\
\hline $\mathbf{2 0 1 0}$ & $73,722,988$ & 15.90 & 76.3 & 23.7 \\
\hline $\mathbf{2 0 1 8}$ & $82,003,882$ & 14.7 & 92.3 & 7.7 \\
\hline
\end{tabular}

Source: TurkStat 2012, p. 4-5 and p. 9 and Results of Population Censuses, 1927-2000 and results of Address Based Population Registration System, 2007-2018

\section{AE in the Republican Revolution and in the Early Republican Period}

The history of modern adult education in Turkey dates back to the late nineteenth century. ${ }^{4} \mathrm{AE}$ was both institutionalized and popularized during the early Republican era, which started with the proclamation of the Turkish Republic in 1923. Adult education was one of the leading means of construction and consolidation of the culture and identity of the citizens of the young republic. The strategic importance of adult education for the young Turkish State was paramount as it made a strong impact on citizens in a short time. The main institution in charge of adult education from 1923 to 1950 were the "people's houses" (halk evleri), offering education to large masses to bridge the differences in lifestyles among the Turkish people, and to adopt a national(ist) art, worldview, and culture (Sayllan and Yildız 2009).

The foundation of the Directorate General of Public Education under MoNE in 1960 was an institutional milestone for the Turkish adult education system. From the 1970s to the 1990s, the priority of the Turkish adult education system has shifted towards vocational-technical education corresponding to the requirements of the "industrial society" and the massive increase in Turkey's urban population (see Table 5.2). Since the 1990s, with the transition to the "information society" in the context of globalization and neoliberal economic transformation (Sayılan 2001), vocational skills have lost their priority in adult education. Instead, lifelong learning, which aims to develop basic skills to increase participation of the person in all areas of society, has become the priority of adult education.

\footnotetext{
${ }^{4}$ See for the developments in the modernisation process of Turkish adult education before the proclamation of the Republic Okçabol 2006 and Yayla 2009.
} 
The developments in Turkish AE in the 1990s ran in the same direction as the developments in Europe. As it is mentioned in the first Chapter of this book in the most recent decade, developments and policies related to adult education have been strongly influenced by the market-oriented approaches of social inclusion. The market-oriented vision of AE aims at strengthening the employability and entrepreneurship. Neo-liberal trend in the development plans of Turkey for 1990-1994 and 1996-2000 changed the priority in adult education policies to address the human resources requirements of the market and had the objective of ensuring a flexible restructuration of the educational system to allow internal and external transfers between formal and non-formal education. Adult education was turned into a dynamic sector that was open for various forms of cooperation among national, local, international, public, private and civil players and that required a diversity of programs (EAEA 2011). The General Directorate in charge of adult education was finally renamed as Directorate General of Lifelong Learning (DGLLL) in 2011. Restructuring the Public Education Centres (PEC) and vocational course centres of local administrations as lifelong learning centres, and qualitatively and quantitatively improving the educational activities on basic skills at these centres was set as an objective of public policy under the 10th Development Plan (2014-2018).

\section{AE in Turkey Today: Framework, Basic Statistics and Challenges}

According to EUROSTAT data from 2013, LLL participation rate in the EU is $9 \%$ on average. This rate is only $3.2 \%$ in Turkey. As a result of this deficiency, Turkey's Lifelong Learning Strategy Paper 2014-2018 identifies the following two priorities of Turkish AE policy: increasing LLL culture and awareness and increasing the access to LLL opportunities. ${ }^{5}$ Further, increasing the participation of vulnerable groups in adult education programs appears to be of great importance. All policy documents related to adult education include the category of "disadvantaged". The category "disadvantaged" was defined in official documents of Turkish AE very similarly to "vulnerable", one of the key concepts of the EduMAP project. The category of disadvantaged includes the disabled, women, the elderly, ex-convicts, juveniles and young people at risk of crime or long-term unemployed, unemployed youth, seasonal workers and refugees.

\footnotetext{
${ }^{5}$ https://ec.europa.eu/epale/en/resource-centre/content/turkey-national-lifelong-learningstrategy-paper-2014-2018-0
} 


\section{Framework and Basic Statistics}

In the actual landscape, there is a diversity of actors in adult education in Turkey. Turkish Statistical Institute's Non-Formal Education Statistics 2016 has classified these actors as ministry and affiliated institution, university, municipality, confederation or union, foundation and society, and listed the numbers of courses, participants and graduates for the years 2015 and 2016 (Table 5.3).

Among all of the actors in the Turkish adult education sector, the DGLLL under the Ministry of National Education (MoNE) is in a privileged position. It produces services and is also in charge of developing a national strategy for adult education, ensuring coordination between the stakeholders in adult education, and overseeing relevant activities. Across Turkey, 990 PEGs and 20 Maturation Institutes are operating under the DGLLL. As of 2017, a total of 340,000 courses have been given across 299 branches, and approximately seven million people were registered for these courses.

Turkish Employment Agency (IŞKUR) is one of the leading public actors in adult education services. The Agency has a high capacity for developing international cooperation for employment and education projects and for using foreign funds. Also the concepts and target groups of the AE programs organized by the ISSKUR are obviously in line with the active citizenship (AC) vision in Europe. There are many programs aiming at the active participation of young adults in the economy and their empowerment in this way. NEET is one of the population groups that İSKUR is trying to reach through AE programs. With the concept of "Active Workforce Programs", İŞKUR organizes "entrepreneurship training programs", "on-the-job training programs", and "vocational training courses." According to recent data, more than $50 \%$ of the participants of these courses are women, approximately $50 \%$ of all participants are aged between 15 and 29, and most of the participants are dropouts. Migrants and refugees are one of the relatively new target groups of İSKUR. In this context, the priority for İ̧KUR is to generalize its vocational and

Table 5.3 Non-formal education activities by institutions and organizations

\begin{tabular}{l|l|l|l|l|l|l}
\hline & \multicolumn{3}{|l|}{$\begin{array}{l}\text { Number of } \\
\text { courses }\end{array}$} & \multicolumn{2}{l}{$\begin{array}{l}\text { Number of course } \\
\text { participants }\end{array}$} & \multicolumn{2}{l}{$\begin{array}{l}\text { Number of participants } \\
\text { completed the courses }\end{array}$} \\
\cline { 2 - 7 } organization & 2015 & 2016 & 2015 & 2016 & 2015 & 2016 \\
\hline Total & 71,127 & 72,167 & $5,711,116$ & $7,611,505$ & $5,526,014$ & $7,425,138$ \\
\hline $\begin{array}{l}\text { Ministry and } \\
\text { affiliated institution }\end{array}$ & 37,358 & 35,367 & $2,856,478$ & $4,686,269$ & $2,802,955$ & $4,650,878$ \\
\hline University & 4671 & 4748 & 321,065 & 415,502 & 304,262 & 384,771 \\
\hline Municipality & 19,115 & 18,571 & $1,450,945$ & $1,781,471$ & 1346.538 & $1,666,217$ \\
\hline $\begin{array}{l}\text { Confederation or } \\
\text { union }\end{array}$ & 618 & 781 & 62,908 & 85,141 & 62,847 & 85,071 \\
\hline $\begin{array}{l}\text { Foundation and } \\
\text { society }\end{array}$ & 9365 & 12,700 & $1,019,720$ & 643,122 & $1,009,412$ & 638,201 \\
\hline
\end{tabular}

Source: TurkStat Newsletter August 24 2017, Issue: 24678 
career consulting services and active workforce programs among refugees (İŞKUR 2017: 50, 73-74).

In adult education, there is a diversity of service providers and of the forms of cooperation among these actors. They predominantly work together in projectbased and time-limited cooperation activities. The PEGs with their infrastructure, trainers and educational materials, are one of the most important business partners in adult education programs and/or social responsibility projects that are developed by these actors and other social constituents. DGLLL has signed 114 cooperation protocols which are still valid as of $2019 .^{6}$

\section{Challenges}

EduMAP project aimed to answer the following research question: What policies and practices are needed in the field of adult education to include young adults at risk of social exclusion in active participatory citizenship in Europe? The size, composition and other characteristics of young people that are Neither in Education nor in Employment or Training (NEET) in Turkey is crucial to understand the background and need for AE among young adults. As Susanli (2016: 44) emphasizes the youth labor market in Turkey is characterized both by high levels of unemployment and inactivity. But while many studies investigate the problem of youth unemployment in Turkey, very few of them take into account the NEETs. See Göksen et al. (2016) for a comparative research of NEET status by gender and migrant status in EU on the base of EU-SILC (European Union Statistics on Income and Living Conditions).

Turkey has the highest NEET rate among OECD countries. As Table 5.4 shows according to the Education at a Glance Report 2018 in all following age groups, 15-19, 20-24 and 25-29, is the NEET rate in Turkey still more than two times above the OECD average, despite the positive developments in the last decade.

On average across OECD countries, $14.5 \%$ of 18-24 year-olds are neither employed nor in education or training. As we see in Table 5.5 in Turkey, the share of NEETs among 18-24 year-olds exceeds 30\% (Erdoğan et al. 2017: 5-7). The percentage of NEETs includes both those who have not managed to find a job (unemployed) and those who are not actively seeking employment (inactive). EAG

Table 5.4 NEET rate (\%) in Turkey and the OECD average by year and age group

\begin{tabular}{l|l|l|l|l}
\hline Age groups & OECD 2006 $(\%)$ & OECD 2017 $(\%)$ & Turkey 2005 $(\%)$ & Turkey 2017 $(\%)$ \\
\hline $15-19$ years & 8.3 & 6 & 37.7 & 15 \\
\hline $20-24$ years & 16.4 & 16 & 47.2 & 33 \\
\hline $25-29$ years & 18.4 & 18 & 42.2 & 35 \\
\hline
\end{tabular}

Source: EAG 2018, Fig. A2.3 and Table C4.2A

${ }^{6} \mathrm{http}: / /$ hboprojeler.meb.gov.tr/protokol-liste.html 
Table 5.5 Percentage of 18-24 year-olds not in education, by work status (2017)

\begin{tabular}{|c|c|c|c|c|c|}
\hline \multirow[b]{3}{*}{ Country } & \multicolumn{5}{|l|}{ Not in education } \\
\hline & \multirow[b]{2}{*}{ Not in education total } & \multicolumn{3}{|l|}{ NEET } & \multirow[b]{2}{*}{ Employed } \\
\hline & & Unemployed & Inactive & Total & \\
\hline Turkey & 59.3 & 8.9 & 22.3 & 31.1 & 28.2 \\
\hline OECD & 47.4 & 6.0 & 8.4 & 14.5 & 32.9 \\
\hline EU 22 & 43.7 & 6.8 & 7.4 & 14.3 & 29.4 \\
\hline
\end{tabular}

Source: EAG 2018, Table A2.1

2018 notices that in Turkey approximately $45 \%$ of the female population in the age group of 18-24 has the status of NEET. This rate is far above the OECD average of $15 \%$. Moreover, more than $80 \%$ of these women are in the status of inactive NEET. The OECD average is around 65\% (EAG 2018, Figures A2.2 and A2.5.). In today's Turkey the group of women NEETs with extreme high rate of inactive young women represents one of the major challenges for the AE System. This challenge acquires a new dimension and dynamic with the recent inflow of refugees to Turkey.

\section{How Does the AE Sector in Turkey Respond to the Inflow of Syrian Refugees?}

Since 2016, the Republic of Turkey follows a policy aimed at co-ordinating and monitoring the whole area of adult education organised both by non-governmental actors and the public authorities. In this background, new institutions, new legal regulations and new statistical data have emerged. Legal and institutional changes became necessary to ensure that refugees can benefit from adult education services (Bircan and Sunata 2015; Emin 2016; Unutulmaz 2019).

The Ministry of Interior, Directorate General of Migration Management signed a cooperation protocol with the DGLLL on 25 April 2016 to organize Turkish language courses, vocational courses and social skills courses for foreigners under temporary protection in Turkey (Emin 2016). In relation to this, the Department of Migration and Emergency Training was established under DGLLL on 16 May 2016 to "develop, implement, monitor, and evaluate policies on training in migration and emergencies" (DGLLL 2016). Responsibilities of the department include ensuring coordination of national and international training projects on migration and emergencies, cooperating with national and international institutions and developing the relevant training materials. One of the most important measures that DGLLL has taken in relation to education of foreigners/refugees was to ensure effective public promotion of the services in the community of refugees. To do this, one million brochures, short texts containing information on open schools, vocational courses and other AE programs, were distributed across Turkey in Arabic language. 
In principle, Turkey acts on a vision to ensure that all members of society can participate in all education modules under equal terms, and to develop a system that allows adults to gain a new vocation or obtain diplomas for their existing vocations. The most important outcome of the efforts to bring necessary changes in the legislation because of the refugee flows has been the Directive on Lifelong Learning Institutions which came into force on 11 April 2018.

\section{Statistics Concerning AE Programs Attended by Syrians}

Numerous civil initiatives on education of Syrians have been developed between April 2011 and July 2017. Yet there does not exist data that provides a sound overview of these activities. Since July 2017, local, national and international actors in civil society can offer educational services for refugees legally only on the condition that they sign protocols with DGLLL. The DGLLL justifies this decision with improving efficiency of trainings and preventing any abuse of educational activities that may lead to problems of security.

Directorate General of Lifelong Learning announced its most detailed data on the participation of refugees under the title of "foreigners under temporary protection" in its Monitoring and Evaluation Reports 2017 (DGLLL 2017). As can be seen in Table 5.6, more than 28,500 Syrians from all age and gender groups participated in the Turkish language courses. 14,200 participants were women over 18 years old, which represents a significant percentage. According to Table 5.7, approximately 66,000 people attended other courses than Turkish language courses, including 55,000 students in "general courses" and 10,500 students in "vocational-technical courses." However, the number of students by year demonstrates that the number of women and men has been constantly decreasing in all courses since 2015. For example, the number of people who attended the Turkish language courses in 2015 was 70,000, which went down to 62,000 in 2016 and to 28,000 in 2017 (Table 5.8). The decrease in the participation to vocational-technical courses is even more dramatic: there were 61,000 students in 2015, and the number fell to approximately 16,000 in 2016 and to 10,000 in 2017 (Table 5.9).

DGLLL did not make any explanation in its 2017 annual report regarding the systematic decrease in Syrian refugees' participation in courses. However, the reasons for the systematic decrease in the participation of Syrian refugees in DGLLLcontrolled educational activities should be examined in multiple ways.

Table 5.6 Turkish courses by age groups, Syrian trainees data (2017)

\begin{tabular}{l|l|l|l|l}
\hline Gender & Age 6-12 & Age 13-17 & Adults & In total \\
\hline Men & 2408 & 330 & 9070 & 11,808 \\
\hline Women & 2249 & 296 & 14,212 & 16,757 \\
\hline Total & 4657 & 626 & 23,282 & $\mathbf{2 8 , 5 6 5}$ \\
\hline
\end{tabular}

Source: MEB DGLLL 2017 Monitoring and Evaluation Report, p. 131 
Table 5.7 Number of Syrians in Non-Turkish courses (2017)

\begin{tabular}{l|l|l|l}
\hline Gender & Vocational and technical & General & In total \\
\hline Women & 7,113 & 32,346 & 39,454 \\
\hline Men & 3,166 & 23,094 & 26,260 \\
\hline Total & 10,279 & 55,440 & $\mathbf{6 5 , 7 1 9}$ \\
\hline
\end{tabular}

Source: MEB DGLLL 2017 Monitoring and Evaluation Report, p. 131

Table 5.8 Turkish courses given to Syrian trainees by years (2015-2017)

\begin{tabular}{l|l|l|l}
\hline \multirow{2}{*}{ Year } & \multicolumn{3}{l}{ Turkish as foreign language } \\
\cline { 2 - 4 } & Women & Men & In total \\
\hline 2015 & 40,904 & 28,639 & 69,543 \\
\hline 2016 & 35,985 & 26,201 & 62,186 \\
\hline 2017 & 16,757 & 11,808 & 28,148 \\
\hline Total & 93,646 & 66,648 & 159,887 \\
\hline
\end{tabular}

Source: MEB DGLLL 2017 Monitoring and Evaluation Report, p. 131

Table 5.9 Vocational technical courses by years (2015-2017), Trainees data

\begin{tabular}{l|l|l|l}
\hline \multirow{2}{*}{ Year } & Vocational and technical & \\
\cline { 2 - 4 } & Women & Men & In total \\
\hline 2015 & 36,229 & 25,115 & 61,344 \\
\hline 2016 & 11,124 & 4421 & 15,545 \\
\hline 2017 & 7113 & 3166 & 10,279 \\
\hline Total & 54,466 & 32,702 & $\mathbf{8 7 , 1 6 8}$ \\
\hline
\end{tabular}

Source: MEB DGLLL 2017 Monitoring and Evaluation Report, p. 133

\section{AE for Refugee Integration: How AE Programs Are Designed to Address Refugees with Multiple Vulnerabilities for Social Integration}

As explained above, the Syrians in Turkey present a quite complicated case because of their massive number and low education level for AE policies aiming at integration of refugees and enhancing their active citizenship capacities. To reiterate very briefly, this is mainly because of several characteristics of the Syrian refugee population in Turkey: Demographically, it is very young; socio-economically, it is generally un-educated, poor, and without qualifications; socio-psychologically, it suffers from being uprooted and traumatised by an on-going civil war; legal and politically, it has an unclear future in Turkey, which is reflected in their legal status which is 'persons under temporary protection'.

The AE programmes bear special significance in the Turkish case regarding the integration of Syrian refugees and helping them obtain APC qualities for several reasons. First of all, as it was discussed at length, the immigration of a massive number of Syrians in Turkey took place in a quite short period of time. Considering the demographic characteristics of these new arrivals and the fact that Turkey 
already has a large and young population itself, the burden placed on the national education system was enormous (Erdoğan 2014). In addition, the perception and expectation of temporariness of Syrians in Turkey has meant that Turkey did not begin to adopt long-term education policies from the outset (Kirisci 2014; Icduygu 2015). When the permanent settlement of a large number of Syrians in the country became undeniable, the government did start to take decisive steps to integrate as many school-aged Syrians into formal schooling system as possible. At this point, however, it was quite late for a large number of Syrians, who, in the absence of such a comprehensive education policy addressing their particular conditions, had not had access to formal schooling in the Turkish national education system. It should be noted that the initial perception of temporariness was mutual, being both on the part of the Turkish government and the Syrians themselves, which made it further difficult for many Syrians to have, or demand, access to education in Turkey (Unutulmaz 2019).

Moreover, at the time of writing, around 55\% of the registered 3.6 million Syrians in Turkey are beyond the age 18 (Table 5.1). In other words, even if it can be assumed that all school-aged Syrians could be fully integrated into the formal education system, there is still a large number of adults who will need AE opportunities. It also needs to be remembered that the Syrian refugees in Turkey are forced migrants, who were displaced by a bloody civil war that still continues into its ninth year. There are obvious psychological implications of such life experiences, which would be the subject of another paper. The fact, however, that their lives are interrupted by the war and by the eventual move to another country needs to be remembered. In a context where even the most educated and highly-skilled are suffering the implications of moving to a completely different system where their qualifications mean very little, if at all; those with interrupted educational backgrounds and no qualifications crucially need AE programs. This has been even more harmful for the Syrians in Turkey since, as suggested earlier, they already have relatively low educational attainment levels (see the section on 'education indicators' of Syrian refugees above).

The AE policies and programs could help such refugees in a great number of ways to adapt to their new social surroundings, obtain and develop APC skills, and integrate in their new society. One of the most important of such ways is language acquisition, which is absolutely crucial for integration (Eroğlu et al. 2017; Erdoğan 2017). While Turkey has been in its 'migration transition' for years preceding the arrival of Syrians in 2011, in which it has been transforming from a mainly emigration/origin country into an immigration/destination one, it still lacks the necessary legal and institutional infrastructure to respond to this change (Kirisci 2014). Thus, for instance, there are no widespread and accessible Turkish language courses designed for immigrants and refugees. This is quickly changing in Turkey and AE programs and initiatives, such as the ones scrutinized in the EduMAP project, are an essential aspect of this. The importance of learning the language in the host context cannot be emphasized enough. It is not only a minimum requirement for integration for refugees; it is a basic survival skill. Without the necessary minimum language abilities, the refugees will inevitably get isolated and excluded from the society, be 
pushed into a life in segregated enclaves, and marginalisation becomes a likely destination.

Almost as important as language is the ability of refugees to financially support themselves (Erdoğan 2017). While various support mechanisms could be developed by the state, and they are in place in the Turkish case through several public programs as well as EU funding, these can only be temporary half-measures. In the medium and long-run, refugees need to improve their employability in a new labour market where their skill sets and qualifications might not match the demands. Here, as well, the AE programs are of crucial importance. Mainly through Vocational Education and Training (VET) programs that could be designed according to the profile of the targeted Vulnerable Young Adults (VYA) population and the demands and requirements of the local labour markets, the AE programs provide the necessary flexibility and effectiveness, as the Turkish case also demonstrates. It needs to be stressed that even though the VET programs might not immediately and/or directly lead to paid employment, they improve not only the human capital of refugees but also their social capital as well as self-confidence.

Lastly, AE programs are essential for integration because they provide convenient channels through which refugees interact with their wider community as well as the mainstream society (Eroglu et al. 2017, 213). Social interaction serves as a virtuous cycle whereby more social interaction leads to increased language fluency, greater social capital, and extra cultural capital of the host context as well as more social interaction. As it will be further described in more detail below, a majority of AE programs that target Syrian refugees in Turkey are designed in a more comprehensive approach on social inclusion and usually delivered by community centres that establish trust-based relations with the refugees. In other words, the AE programs are usually seen not merely as tools for education on their specific issues of focus, e.g. language learning or vocational training in hairdressing; they are rather designed to be an element in a more holistic program. These programs usually include extra-curricular events aiming to increase social interaction with the native society, to teach various cultural norms and values, and to prepare the Syrian refugees for a more independent life in Turkey through empowerment (see below for details).

\section{How Are AE Programs Designed in Turkey to Address the Multiple Vulnerabilities of Syrian Refugees}

To help Syrian refugees develop their APC skills and effectively integrate in Turkish society, a plethora of AE programs are being designed and implemented. In the framework of EduMAP project, Good Practice cases involving the so-called community centres were identified and investigated. While naturally there are many other programs, the AE programs discussed in this study are the ones coordinated by these community centres as part of an integrated, holistic approach. 
The term Multifunctional Community Centre (MCC) is used to describe various institutions in different contexts. Therefore, before moving further into the specificities of AE programs, it is necessary to define what a community centre is in the Turkish context. A MCC is one that aims to provide an integrated and holistic service approach to become the single address that these groups would go to for a wide variety of services. These centres also aim to respond to the specific and special needs of the vulnerable target groups. In addition, they typically offer their services on an open-access manner whereby targeted individuals could simply walk in. In addition, these centres usually establish a trust-based relationship with the targeted individuals. Lastly, they collect data from the individuals through their registration and create an extensive database, which helps them to design and revise programs.

In our case, the idea at these MCC is the following: provide the most basic and urgent services for the refugees such as health services, psychological counselling, legal advice, financial support, and, of course, education programs in one convenient place. Once refugees arrive at these centres, they are welcomed at the reception by experts who register them while learning about the needs, requirements, and demands of the refugees. Then, this person directs the refugee to relevant departments depending on their needs. Starting from this first encounter, a continuous relationship is built between the refugee and the centre through means of constant communication, which fosters trust through time.

AE programs are a crucial part of the integrated services approach. While the Turkish language courses for all age groups continue throughout the year, specific VET programs take place at specific times on relevant subjects to increase the employability of the refugees. The subjects of the programs as well as details concerning scheduling of the classes etc. are determined by taking account of the specific needs and requirements of the refugees. During registration as well as at the later encounters, the information flows from the refugees toward the AE coordinators. Crucially, information also flows in the opposite direction whereby information about the existing and prospective AE programs are disseminated to the target VYA groups. And lastly, the continuous communication and trust-based relationship allows for the coordinators to receive valuable feedback about the AE programs thereby giving them the opportunity to revise and improve programs (see Fig. 5.2).

It needs to be highlighted here that the flow of information between the refugee VYAs and the community centres is continuous and bi-directional. Therefore, as it can be seen in Fig. 5.2, there is a continuous flow of information from the VYA learners in the form of requests, demands, and needs, which are either collected by the community centres during registration or afterwards using various channels, repeatedly. So, it is not just a one-off assessment but a dynamic process of collecting information continuously. Also remarkably, once the VYA learners realise that the community centres are open and welcoming for their demands and suggestions, they become more active parties of this process through coming up with ideas and requests of their own, even when they are not directly asked about them. The same applies for information from the VYA learners in the form of feedback on how the various AE programs they participated worked. They provide the community 


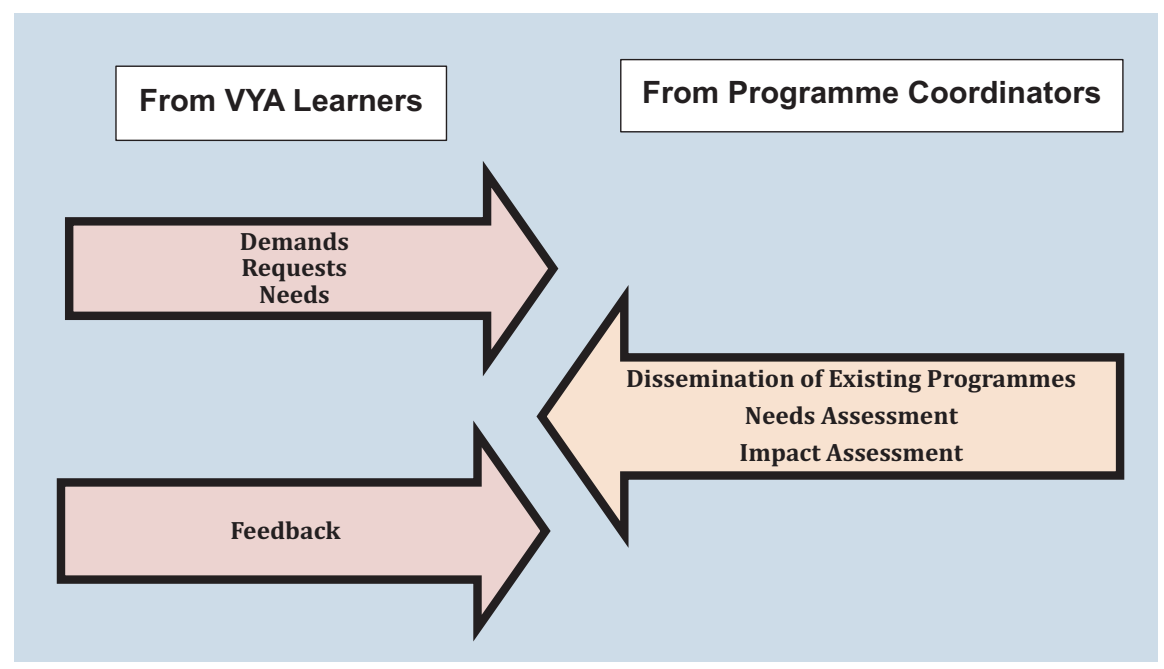

Fig. 5.2 Flow of information regarding AE programs between refugee VYAs and program coordinators at the community centres

centres with invaluable information about the usefulness, effectiveness, and overall success of the programs so that program coordinators could use this information to improve the existing programs and design more effective ones. On the other direction, there is a continuous flow of information from the program coordinators at the community centres towards the targeted VYA groups in the form of dissemination of existing or upcoming AE programs, their assessments of the needs of the VYA learners, and their own assessment of the impacts of various AE programs.

The crucial point here is that the program coordinators neither assume that they know what is good, useful, and/or necessary for the targeted VYA learners; nor do they simply try to provide exactly what is requested by these learners. Instead, they try to create an atmosphere in which the VYA learners are active participants in the planning, design, and implementation of the right $\mathrm{AE}$ programs, at the right time, with the right people. This is a mutual learning process and a collective effort, often frequent trial-and-error sequences, which is made possible by the described continuous and mutual flow of information.

In the next part, a more detailed description and discussion of various specific AE programs from the Good Practice cases will be provided. 


\section{The Holistic View on Social Inclusion and Development of APC Skills}

The above described and discussed integrated service approach where AE programs occupy a central place offers significant benefits for the VYAs as well as the policy makers. First of all, considering the fact that the refugees don't know the system and institutions in their new host context, refugees tend to remain in regular contact with a centre that provides several services and that acts as a guide and advisor concerning the services that it doesn't provide itself. This creates strong and stable communication between the refugees and the centre, as discussed above. This communication is the bedrock on which effective and useful AE programs on language, VET or hobbies could be designed, advertised, and implemented.

Secondly, the benefits acquired from these AE programs are not only related to their specific subject matter. To the contrary, particularly concerning specific VYA groups such as the women refugees, the main benefit of these programs is reported to be the acquired sense of confidence. Many respondents suggested that through taking part in these programs, they realised what they are actually capable of doing. In the words of one Syrian women respondent "before coming here I was afraid of even going out of my house. Now, I feel like I can do anything by myself. I can earn my own living, I can stand on my own."

This sense of confidence acquired was closely related with the sense of being independent that was mentioned by many Syrian women. Accordingly, while they used to feel dependent on either their fathers or husbands in the past, through participating the AE programs, they feel much more independent. This sense of empowerment surely helps APC competences to develop.

Another important characteristic of MCC and their AE programs is their flexibility. Such community centres are based in the local context and are very active in the field. Therefore, they are aware of the local peculiarities. They are, on the other hand, in constant cooperation with national and international stake-holders, which include the state, national civil society, international organisations such as UN bodies or the EU, and INGOs from across the globe. This makes them perfectly situated to channel both the resources from the international and national levels to the local, and to customize projects and programs designed by these stakeholders depending on the local conditions.

Lastly, the MCC are perfect candidates for serving as intermediary actors between the thousands of VYAs that they serve in their localities and the state as well as the above-mentioned other actors. Again, here the bridging role of the community centres would work in two directions: on the one hand, they provide a gateway for the above mentioned national and international actors to reach out to and engage refugee VYAs. On the other hand, it assists the refugees themselves to learn about and interact with the outer world. 


\section{Concluding Remarks and Future Prospects}

This chapter utilized the EduMAP project findings in the Turkish field study to discuss how the Turkish AE sector have responded to the Syrian refugees and what role it does and could play in their social integration and enhancement of their APC skills. This concluding part will briefly summarize and recap the main parts of the chapter and will underline its main findings and arguments.

While the official discourse is still talking about the temporariness of the Syrian immigrants in Turkey and their eventual return to Syria, it is becoming increasingly clear that a significant number of Syrian refugees will remain in Turkey permanently no matter what happens in Syria and beyond (Erdoğan 2017). Even though the legal status of Syrians, i.e. 'persons under temporary protection', and political discourse about them imply otherwise, the Turkish government and state institutions are also increasingly, albeit not explicitly, acknowledging this fact (Eroglu et al. 2017; Unutulmaz 2019). Social integration of refugees is one of the hottest topics in the political agenda in Turkey, as it is in many different countries around the globe. This chapter has attempted to show that AE policies and programs already are, and will increasingly be in the future, one of the most effective, versatile, and flexible tools to use for the social as well as economic, cultural, and eventually even political integration of Syrians by a diverse set of policy makers at different levels.

Adult Education has a long history in Turkey, as it was described above, and it has long been seen as an important tool for the policy makers to address various vulnerabilities, particularly illiteracy and failure to access education. It is also relevant for the topic of this paper that AE has been seen as an important tool not merely for education and technical training per se, but also for construction of certain identities and upholding certain norms and values, i.e. those of the republic for constructing good citizens (EAEA 2011). Today, similarly, the AE programs are seen as one significant part of a more comprehensive approach targeting social integration of a large population of refugees. The review in this chapter amply demonstrates that the potential of $\mathrm{AE}$ as this effective, versatile, and flexible tool is fully acknowledged.

There is, certainly, a lot to be improved in Turkey in terms of how AE programs are used for the social integration of VYA refugees. However, there is a number of very significant lessons to be learned and successful examples to be drawn from the Turkish experience, as well. Arguably, one of the most significant of these is the holistic approach that is seen in the MCC model in Turkey. Acknowledging the fact that refugees bear multiple vulnerabilities and suffer from complex disadvantages, this integrated service approach which includes guidance and consultancy, financial support and psychological counselling, legal advice and medical attention, among other things, helps establish a strong and trust-based relationship with individuals and communities at the local level. What is more, these centres also function as trusted emissaries and bridging institutions between these VYA groups and the Turkish state institutions, in other words between the local and the national levels.

A second crucial lesson from the Turkish case is on the importance of communication and healthy information flows between the AE program coordinators and the VYA groups. This can be seen as a mundane point to make, yet the importance of 
establishing open, dynamic, mutual, and continuous communication could not be overstated. Since the importance of local context is equally universally acknowledged (Hovil 2014), it must not be forgotten that the 'recipe for the perfect AE program' that will work equally effectively everywhere cannot be created. It is much safer to argue, however, that the custom-made AE programs that will work at a local context need to be the product of a combination of what the program coordinators have, e.g. a strategic vision, pedagogical tools, measurable objectives, and so on, on the one hand; and what the target audience of those programs needs and requests. Here, it needs to be highlighted that what the VYA learners request is quite easy to find out, through simply asking them. More important part, however, is figuring out what they need and it should be beyond what the VYA learners subjectively believe they need. The Turkish experience is a good example showing how the open information channels help the coordinators to better understand what the VYA learners need and combine this information with their own strategic vision and objectives in designing AE programs that would be more likely to work.

Turkey is facing many challenges in terms of social integration of Syrian refugees in the country and its use of AE programs requires improvement with many respects. First of all, it needs to be acknowledged that the numbers of the refugees are highest in the world. Nevertheless, there is an urgent need to formulate a stronger long-term vision concerning the future and social integration of Syrians in the country. The actual place and significance of AE policies and programs, and their local implementation, could only be properly mapped out within such a macro-level national strategic vision. Secondly, in a related manner, the AE programs addressing social integration of VYA refugees could be much better coordinated. Such coordination could decrease the waste of financial, physical, and human resources, as well as enhancing the success of AE programs by learning from each different case. Thirdly, there is a need for better cooperation with different actors in the AE field. So far, the contribution of universities, the ties with the private sector companies, and the constructive involvement of NGOs and INGOs appear to be very limited. Further involvement of and cooperation among these and other potential stakeholders are necessary. Lastly, designing and implementing effective AE programs is costly. As mentioned above, it involves financial costs as well as use of physical buildings and material, and human labour. While Turkey has done an exceptionally good job of devoting a significant chunk of its budget to costs created by the current refugee situation, the longer-term question of social integration will pose further strains on the country financially.

\section{References}

Anderson, D., \& Niomi, J. (1969). Adult education and disadvantaged adult, ERIC clearing house on adult education. New York: Syracuse.

Bircan, T., \& Sunata, U. (2015). Educational assessment of Syrian refugees in Turkey. Migration Letters, 12(3), 226-237.

Convention and Protocol Relating to the Status of Refugees. (1951). https://www.unhcr. org/3b66c2aa10; 30.06.2019 
DGLLL. (2016). Regulation. https://hbogm.meb.gov.tr/www/hayat-boyu-ogrenme-kurumlariyonetmeligi/icerik/791

DGLLL. (2017). İleme Değerlendirme Raporu. http://hbogm.meb.gov.tr/dosyalar/izlemedegerlendirmerapor/2017/mobile/index.html (30.06.2019).

DGLLL. (2018). İzleme Değerlendirme Raporu. http://hbogm.meb.gov.tr/dosyalar/izlemedegerlendirmerapor/2018/mobile/index.html (30.06.2019).

DGMM. (2020). Temporary protection. https://www.goc.gov.tr/icerik6/ temporary-protection_915_1024_4748_icerik

EAEA (2011). Country Report Turkey. (Helsinki). www.eaea.org/country/turkey. Last accessed 11 Aug 2020.

Education at a Glance. (2018). OECD indicators. https://www.oecd-ilibrary.org/education/ education-at-a-glance-2018_eag-2018-en (30.06.2019).

Emin, M. N. (2016). "Education of Syrian children in Turkey: Education policies" (in Turkish). Ankara: Report for SETA.

Erdoğan, M. M. (2014). Syrians in Turkey: Social acceptance and integration. Ankara: HUGOHacettepe University Migration and Politics Research Centre. http://fs.hacettepe.edu.tr/hugo/ dosyalar/TurkiyedekiSuriyeliler-Syrians\%20in\%20Turkey-Rapor-TREN-19022015.pdf; 14.03.2019.

Erdoğan, M. M. (2017). Urban Refugees from "Detachment" to "Harmonization" Syrian Refugees and Process Management of Municipalities: The Case of Istanbul, Marmara Municipalities Union (MBB).

Erdoğan, M. M. (2018). Suriyeliler Barometresi-2017: Suriyelilerle Uyum İçinde Yaşamın Çerçevesi (Syrians-Barometer-2017: A framework for achieving social cohesion with Syrians in Turkey). İstanbul: Bilgi Üniversitesi Yayinevi.

Erdoğan, M. M. (2020). Syrians-barometer-2019: A framework for achieving social cohesion with Syrians in Turkey. Ankara: TAGU-UNHCR, Orion Yayınevi.

Erdoğan, E. et al. (2017). Being a NEET in Turkey: Determinants and consequences. Power2Youth working paper, No: 30, April 2017.

Eroğlu, D., Unutulmaz, K. O., \& Sirkeci, I. (Eds.). (2017). Turkey's Syrians: Today and tomorrow. London: Transnational Press. ISBN: 978-1-910781-74-6.

European Commission. (2017) A Home away from Home: Supporting Syrian Refugees in Turkey. Accessible online at https://ec.europa.eu/fpi/sites/fpi/files/eu-showcase-syria_final_0.pdf; 16.06.2019.

Gökșen, F. et al. (2016) Vulnerable youth \& gender mainstreaming (STYLE working papers, STYLE working papers). http://www.style-research.eu/publications/working-papers

Hovil, L. (2014). Local Integration. In E. Fiddian-Qasmiyeh, G. Loescher, \& Long, K. And Sigona, N. (Eds.), The Oxford handbook of refugee and forced migration studies. Oxford: Oxford University Press.

Içduygu, A. (2012). Demography and immigration/emigration. In M. Heper \& S. Sayarı (Eds.), The Routledge handbook of modern Turkey (pp. 328-337). Abingdon: Routledge.

Içduygu, A. (2015). Syrian refugees in Turkey: The Long road ahead. Report for Transatlantic Council on Migration, Migration Policy Institute.

IOM. (2017) World migration report 2018. International Organization for Migration. ISBN 978-92-9068-742-9. Accessible online at https://www.iom.int/sites/default/files/country/docs/ china/r5_world_migration_report_2018_en.pdf; 29.06.2019.

İşKUR. (2017). Faaliyet Raporu. https://media.iskur.gov.tr/13578/2017-yili-faaliyet-raporu.pdf (30.06.2019).

Jarvis, P. (2010). Adult education and lifelong learning: Theory and practice (4th ed.). London/ New York: Routledge.

Kirisci, K. (2014). Syrian refugees and Turkey's challenges: Going beyond hospitality. Washington, DC: Report for the Brookings Institution.

Kowalski, T. J. (1988). The organization and planning of adult education. Albany: State University of New York. 
Ministry of Development. (2016, March). First stage needs assessment covering 2016-2018 period for Syrians with temporary protection status in Turkey (p. 5).

Ministry of National Education. (2019). Directorate General of Life Long Learning, Migration and Emergency Education Unit Report. Accessible online at https://hbogm.meb.gov.tr/ meb_iys_dosyalar/2019_06/26115239_14_HAziran__2019_YNTERNET_SUNUUU_pdf; 28.06.2019.

Okçabol, R. (2006). Halk Eğitimi (Yetişsin Eğitimi). Ankara: Ütopya Yayınevi.

Pennacchia, J; Jones, E., \& Aldridge, F (2018). Barriers to learning for disadvantaged groups Report of qualitative findings. Learning and Work Institute. https://assets.publishing.service.gov.uk/government/uploads/system/uploads/attachment_data/file/735453/Barriers_to_ learning_-_Qualitative_report.pdf. Last accessed 21 July 2020.

Sayılan, F. (2001). Paradigma Değişirken: Küreselleşme ve Yaşam Boyu Eğitim. In Cevat Geray'a Armağan (pp. 609-624). Ankara: Mülkiyeliler Birliği Yayını.

Sayılan, F., \& Yildiz, A. (2009). Historical and political context of adult literacy in Turkey. The International Journal of Lifelong Education, 28(6), 735-749.

Susanli, Z. B. (2016). Understanding the NEET in Turkey. Eurasian Journal of Economics and Finance, 4(2), 42-57.

Tight, M. (1996). Key concepts in adult education and training. London/New York: Palgrave.

Toprak, M., \& Erdoğan, A. (2012). Yaşamboyu Öğrenme: Kavram, Politika, Araçlar ve Uygulama (lifelong learning: Concept, policy, instruments and implementation). Journal of Higher Education and Science, 2(2), 69-91.

Turkey National Lifelong Learning Strategy Paper 2014-2018. Accessible online at https:// ec.europa.eu/epale/en/resource-centre/content/turkey-national-lifelong-learning-strategypaper-2014-2018-0; 30.06.2019.

TurkStat. (2012). Istatistik Göstergeler: Statistical indicators 1923-2011. Ankara: Turkish Statistical Institute.

UNHCR. https://data2.unhcr.org/en/situations/syria. Last accessed 30 Jun 2019.

Unutulmaz, K. O. (2017). Integration of Syrians: Politics of integration in Turkey in the face of a closing window of opportunity. In D. Eroglu, K. O. Unutulmaz, \& I. Sirkeci (Eds.), Turkey's Syrians: Today and tomorrow. London: Transnational Press.

Unutulmaz, K. O. (2019). Turkey's education policies towards Syrian refugees: A macro-level analysis. International Migration, 57(2). https://doi.org/10.1111/imig.12476.

Yayla, D. (2009). Türk Yetişkin Eğitimi Sisteminin Değerlendirmesi. Ankara: MEB Yayınları.

Open Access This chapter is licensed under the terms of the Creative Commons Attribution 4.0 International License (http://creativecommons.org/licenses/by/4.0/), which permits use, sharing, adaptation, distribution and reproduction in any medium or format, as long as you give appropriate credit to the original author(s) and the source, provide a link to the Creative Commons licence and indicate if changes were made.

The images or other third party material in this chapter are included in the chapter's Creative Commons licence, unless indicated otherwise in a credit line to the material. If material is not included in the chapter's Creative Commons licence and your intended use is not permitted by statutory regulation or exceeds the permitted use, you will need to obtain permission directly from the copyright holder.

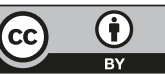

